\title{
JoAquim Manuel de MaCedo e a Abolição da Escravatura
}

\author{
José António Carvalho Dias de Abreu* \\ joseantonioabreu@gmail.com
}

\begin{abstract}
RESUMO: Após a abolição do tráfico negreiro, mas antes das Leis do Ventre Livre, dos Sexagenários, e da Lei Áurea, Joaquim Manuel de Macedo traça, em As vítimas algozes, um plano contra a escravidão que visa a sua abolição.Nessa medida, como obra abolicionista, constatam-se, ao longo dos textos, os constantes apelos do narrador à supressão do que ele considera um «cancro» que corrompe e que degrada o ser humano.Considerando que o mal de tudo veio de África, Macedo entende que o negro reduzido à escravatura provocou a degradação da sociedade, contaminando-a com os seus vícios. Dessa forma, dá-se a conhecer o processo de inversão no sistema escravocrata: a vítima, afinal, é o algoz, enquanto o opressor é vitimizado.
\end{abstract}

PALAVRAS-CHAVE: Literatura; Escravatura; Abolicionismo.

\section{QUE REPRESENTAÇÃO LITERÁRIA DO ESCRAVO ATÉ AO SÉCULO XIX?}

Num século caracterizado por grandes transformações políticas, sociais e culturais, o Brasil de oitocentos procurou denodadamente a sua afirmação enquanto nação independente face a Portugal.

Imbuídos de um espírito romântico e modelar, baseado nos conceitos da liberdade e do nacionalismo, os escritores brasileiros, assumiram conscientemente o objetivo de participar na construção e organização dum novel Brasil.

De Gonçalves de Magalhães, Gonçalves Dias, Álvares de Azevedo, primeiro, seguidos, depois, por Joaquim Manuel de Macedo, José de Alencar, Castro Alves, Manuel António de Almeida e Bernardo Guimarães, até Machado de Assis, entre outros, encetou-se essa tarefa, conciliando a tentativa de autonomia literária com a própria conceção e definição da nacionalidade.

*Doutor em Letras pela Universidade de Coimbra. Professor auxiliar na Universidade de Coimbra. 
Porém, nessa tentativa de erigir uma nação, e contrariamente ao princípio da liberdade em que se fundavam, esses intelectuais e escritores brasileiros, se não esqueceram o negro e o afrodescendente e problematizaram a sua condição servil, não tiveram em conta os seus contributos e importância para esse projeto nacional.

Na verdade, circunscrito à sua condição escrava ou a uma liberdade condicionada a uma política de favor dos ex-senhores, o afrodescendente foi encarado na generalidade dos escritores brasileiros de oitocentos como um ser inferior, a quem era negada, na maior parte das situações, a sua humanidade.

Ao fazer-se uma resenha histórica da presença do negro no Brasil, conclui-se que, inicialmente, após o século XVI, quer o indígena brasileiro quer o escravo africano foram paulatinamente convertidos a uma cultura de matriz ocidental que não era a sua e, nessa sequência, foram sofrendo o que se pode designar por uma desculturação acentuada ${ }^{1}$.

Posteriormente, pode-se dizer que os escravos foram encarados na sociedade brasileira generalizadamente - do final da década de 1850 ao início do século XX - como simples elementos decorativos, como meros figurantes, e, quase sempre, vistos pela ótica de mentalidade burguesa e materialista, cada vez mais emergente, como uma vulgar mercadoria de elevado valor comercial.

Sendo a colonização portuguesa no Brasil narcísica, como considera Heloísa Toller Gomes, o escravo, o outro, «é assimilado à imagem especular do conquistador, confundidose com ela»e, nesse entendimento, perde «a sua verdadeira alteridade», as suas marcas culturais e individualizantes mais intrínsecas, alcançando «uma alteridade fictícia (imagem especular do europeu)» que o configura como o outro europeu (GOMES, 1981, p.13). A partir dessa estratégia precisa e rigorosa na forma como lidar com o escravo, o negro desterrado e despojado da sua cultura metamorfoseia-se num esboço europeu, ocidental:

Tal processo de uniformização do globo, de ocidentalização do recémdescoberto, passou a dirigir os desígnios das organizações sócio-políticas e económicas do Novo Mundo, instituindo a classe dominante como detentora do discurso cultural, discurso europeizante [...]. A cultura oficial assimila, não há dúvida, mas ao assimilar, recalca, hierarquicamente, os valores autóctones ou negros que com ela entram em embate. (GOMES, 1981, p.14)

O escravo, o homem de cor, em pleno século XIX, aparecem assim representados na literatura, por um lado, como seres-objeto na maior parte dos casos caracterizados pela submissão a um senhor bom e generoso, privados da sua individualidade, e, por outro lado, como indigentes e infantis, incapazes de se revoltar e enfrentar uma sociedade que, embora pressionada internacionalmente para reformar o seu sistema esclavagista, se encontrava 
demasiado dependente do trabalho servil nas culturas do algodão e do açúcar, primeiro, e na do café depois.

Não constitui surpresa, portanto, que, ao procurar-se a presença escrava nas obras literárias brasileiras, se constatem somente referências circunstanciais de alguém desprovido de capacidade de raciocínio que cumpre determinadas tarefas. Considerados inferiores, os cativos não são, na globalidade dos textos, personagens principais nem secundárias, mas meros figurantes que permitem compor o espaço social brasileiro.

Por outro lado, se se pensar o ambiente doméstico numa versão quase sempre amenizada que predomina nos textos literários e não o ambiente rigoroso e impiedoso da senzala, o escravo que aparece desenhado é o vulgar criado, o moço de recados, a mucama, o moleque que brinca com os nhonhôs e as sinhazinhas, desempenhando um papel específico e tão secundarizante que quase inexiste.

Compreende-se, desta forma, que após um processo ininterrupto que levou ao esvaziamento e simultâneo recalcamento cultural assomem diversos processos literários de construção simbólica das personagens que representam os escravos, com o fito claro de manter uma estrutura dirigente, em que o senhor branco tem um domínio incontestável e opressivo sobre os cativos.

Assim, seja na senzala ou na cidade, os escravos são elaborados, não poucas vezes, como modelos estereotipados não apenas da indigência, da infantilidade, da animalidade, mas também da insensibilidade, da desonestidade, da malvadez e da falta de escrúpulos. A questão da legitimidade, na manutenção da escravatura, da imoralidade, ou das punições desumanas perpetradas pelos brancos não se coloca até meados do século XIX. A sua existência como sistema de produção económica e organização social não estava em causa.

Todavia, com a pressão externa, sobretudo britânica, para abolir o tráfico negreiro primeiro, e para iniciar um processo conducente à emancipação e libertação dos escravos, depois, os temas relacionados com a abolição da escravatura e as relações entre senhores e cativos começam a ser problematizados de forma mais visível em diversas narrativas, em particular, a partir do final da década de sessenta, recrudescendo o seu número à medida que se foram promulgando outras leis emancipadoras: Ventre Livre (1871), Sexagenários (1885) e Áurea (1888).

É neste panorama que surgem sucessivamente narrativas que abordam a escravidão e a abolição, mesmo que de forma muito heterogénea ${ }^{2}$ Úrsula (1859), de Maria Firmina dos 
Reis; As vítimas algozes (1869), de Joaquim Manuel de Macedo; A escrava Isaura (1875) e Rosaura, a enjeitada (1883), de Bernardo Guimarães; O mulato (1888) e O cortiço (1890), de Aluísio Azevedo; Helena (1876), Iaiá Garcia (1878), As memórias póstumas de Brás Cubas (1881), Quincas Borba (1891), Dom Casmurro (1899), Memorial de Aires (1908); "Virginius" (1864), "Mariana" (1871), “O espelho” (1882), "O caso da vara” (1899), "Pai contra mãe" (1906), e diversas crónicas, de Machado de Assis.

\section{MACEDO E A DEFESA DE UM MUNDO PATRIARCAL}

Centrando-nos em Joaquim de Manuel de Macedo, um dos escritores mais relevantes do século XIX brasileiro, introdutor do romance de costumes no Brasil, com o romance $A$ Moreninha (1844), pode afirmar-se que ele faz parte daqueles que intermediaram a vida brasileira, construíram e modelaram uma determinada mentalidade, em que o cativo e o homem de cor ocupavam ainda um lugar secundário, marcado por uma quase invisibilidade e incontestável inferioridade.

Macedo concorre, como se verificará, para a solidificação de uma sociedade patriarcal que submete o homem de cor, o escravo, ao seu domínio absoluto, embora defenda estrategicamente a emancipação da raça maldita.

Analisando As vítimas algozes, o que se destaca imediatamente é a formulação de quadros-padrão que reproduzem uma sociedade que se mantinha, na essência, esclavagista, e apontam, em simultâneo, soluções para essa realidade ${ }^{3}$.

$\mathrm{Na}$ verdade, nas novelas de 1869 de Macedo, numa dimensão bakhtiniana, um mosaico temático, um campo de ideias comuns que as relaciona entre si e com a própria sociedade.

Nesta medida, em As vítimas algozes, observa-se a construção de uma versão patriarcal da sociedade brasileira, isto é, à elaboração de um esquisso literário, onde o senhor, como figura paternalista, desempenha um papel central na conservação e na consolidação de uma estrutura social de matriz esclavagista.

No entanto, naquele momento da história do Brasil, para apresentar um senhor rigoroso e, ao mesmo tempo, generoso, era necessário esboçar uma realidade menos horrenda que a do cativeiro, onde os cativos não sofressem os castigos e as punições

violentas típicas da senzala. É por essa razão que, como afirma Süssekind, é dentro da casa- 
grande e não na senzala, no caso rural, ou dentro de casa, no caso urbano, que se representa o dia-a-dia da escravatura, que não correspondia à verdade, pois, assim, omitia-se a parte mais violenta da escravidão - o castigo físico (Cf. SÜSSSEKIND, 1982,p. 55).

Com o mesmo entendimento, Jacob Gorender realça, em $O$ escravismo colonial, que «foi com base na escravidão doméstica - assim mesmo focalizada de maneira unilateral que se compôs a visão do patriarcalismo brasileiro» (GORENDER, 1980,p. 466).

Assim, com a escravatura circunscrita à domus do branco, compôs-se uma imagem literária menos violenta de um sistema que, em face dos interesses económicos dos fazendeiros e, em grande parte, dos do Brasil, persistia na manutenção da escravidão.

Com efeito, Macedo, ao colocar os escravos na casa-grande, apresentando-os como pajens, criados, mucamas, amas-de-leite, mostra uma escravidão mais doce, que se compaginava com os interesses e o gosto de um público-leitor burguês, evitando simultaneamente uma imagem do senhor agressivo e violento.

É nesta perspetiva que se enquadram as palavras edulcoradas de Gilberto Freyre, quando, já no século XX, expõe que o Brasil patriarcal concebeu uma sociedade escravocrata mais complacente, mais humana que a britânica ou espanhola:

A casa-grande fazia subir da senzala para o serviço mais íntimo e delicado dos senhores uma série de indivíduos - amas de criar, mucamas, irmãos de criação dos meninos brancos. Indivíduos cujo lugar na família ficava sendo não o de escravos mas o de pessoas da casa. Espécie de parentes pobres nas famílias europeias. À mesa patriarcal das casas-grandes sentavam-se como se fossem da família numerosos mulatinhos. Crias. Malungos. Moleques de estimação. Alguns saíam de carro com os senhores, acompanhando-os aos passeios como se fossem filhos. (FREYRE, 2002: 323)

Por outro lado, reiterando a noção de que o paternalismo era uma doutrina que tinha como objetivo nacional a conceção de uma estrutura ética moralizante demonstrativa de quadro de boas relações entre senhores e escravos, aparecem sobretudo pajens e mucamas que caracterizam os seus amos como o paradigma da afabilidade e da generosidade.

Neste quadro de relações amistosas entre senhores e cativos que sustentará o Lusotropicalismo freyriano, constata-se que o negro e o mestiço, mesmo surgindo mais vezes em obras literárias, apenas desempenham papéis secundarizantes, ou, então, papéis em que são os representantes da malícia, da negatividade e a causa de todos os males na sociedade, de que é exemplo As vítimas algozes, com o malévolo negro e feiticeiro Pai Raiol, o indigente e ingrato crioulo Simeão, a corruptora mucama Lucinda. 
Assim, sem voz própria, pois é o branco que lhe produz o discurso, sem capacidade para escolher o seu destino, já que é o senhor que o orienta, surgindo apenas como objeto, o escravo aparece na literatura como um elemento doméstico e domesticado, sem individualidade e sem capacidade de raciocínio, para melhor conceber uma imagem abominável dos cativos ou um quadro menos violento da escravatura.

\section{AS VIRTUDES SENHORIAIS EM AS VÍTIMAS ALGOZES}

Sem pormenores sobre o proeminente papel desempenhado por Joaquim Manuel de Macedo na sociedade brasileira, não apenas como escritor, mas também como professor e político, é de salientar que, nas Lições, mais do que uma história do Brasil, incutiu em seus alunos, a «própria visão da história pátria» (MARTINS, 1996,p.132).

Essas palavras de Wilson Martins reiteram a noção de que o escritor tem consciência do papel interventivo que deve ocupar, como se vê em apreciações como esta:

[...] é dever de cada um concorrer a seu modo, e nas suas condições para o desenlace menos violento desse nó terrível, e servir a causa mais melindrosa e arriscada, porém indeclinável, que atualmente se oferece ao labor e à dedicação do civilismo, pagaremos o nosso tributo nas proporções da nossa pobreza, escrevendo ligeiros romances.

Trabalhar no sentido de tornar bem manifesta e clara a torpeza da escravidão, sua influência malvada, suas deformidades morais e congênitas, seus instintos ruins, seu horror, seus perigos, sua ação infernal, é também contribuir para condená-la e para fazer mais suave e simpática a idéia da emancipação que a aniquila. (MACEDO, 1991,p4)

À semelhança de José de Alencar, em $O$ demónio familiar ${ }^{4}$, o autor de $A$ carteira de meu tio, sabendo que a sua escrita pode construir sentidos, expõe que a existência da escravatura é perversa e degrada o ser humano.

Com a noção de que a escravatura era um assunto que preocupava cada vez mais a opinião pública e «enlameava» a sua época, Macedo, todavia, não escreveu As vítimas algozes com o desiderato de defender a abolição por causa do sofrimento causado ao escravo $^{5}$. Fê-lo, como se demonstrará, para salvaguardar a segurança dos escravocratas.

Neste sentido, Macedo realça as virtudes dos senhores de escravos que, altruístas, são o exemplo da generosidade com aqueles que, pelas costas, planeiam a sua desgraça, a sua perdição. 
Em "Simeão, o crioulo", os senhores Domingos Caetano e Angélica e a sua filha Florinda são apresentados como uma família exemplar e unida, repleta de qualidades, como a generosidade, a humanidade, e capazes de atos compassivos, ao acolher em sua casa o crioulo Simeão, a quem acabaram por amar:

Havia em seus modos a expansão que só parece própria do homem livre: ele não tinha nem as mãos calejadas, nem os pés esparramados do negro trabalhador de enxada: era um escravo de cabelos penteados, vestido com asseio e certa faceirice, calçado, falando com os vícios de linguagem triviais no campo, mas sem a bruteza comum na gente da sua condição; até certo ponto, pois, aceito, apadrinhado, protegido e acariciado pela família, livre, pelo amor dos senhores. (MACEDO, 1991, p.15)

Mais tarde, na mesma novela, Domingos Caetano surge caracterizado como uma figura tutelar, protegendo os seus. Numa leitura mais ampla, ele pode ser encarado como a metáfora da família brasileira, que importava moldar nessas primeiras décadas após a independência:

Paralítico, e embora certo de morte próxima, um esposo e pai, o chefe de família é ainda e sempre enquanto vivo a providência vidente que vela pelos seus: há nele o amor que só a morte apaga, e que durante os restos da mesquinha vida, todo se entrega aos cuidados que ainda são de si, sendo da família, e sendo d'além-túmulo. (MACEDO, 1991,p. 32)

Salientando-se a sua nobreza de caráter e a preocupação com a família, mesmo diminuído fisicamente, Domingos Caetano procura uma espécie de sucessor, um marido para Florinda que congregue os predicados necessários para garantir a prossecução de uma estrutura assente na figura masculina, ou seja, de um sistema patriarcal.

Tal figura, encarnada por Hermano Sales, surge desenhada desde o início como um homem único, excecional, gentil, honesto, laborioso e tão nobre quanto Domingos (Cf: MACEDO, 1991,p.48).

O instante em que Domingos Caetano, antes da sua morte, prepara o casamento de Florinda, paralelamente à negação da família ao negro, vocacionado só para a luxúria, enfatiza, simbolicamente, que, se a família é vista como a raiz de uma sociedade ${ }^{6}$, o negro não pode ser nunca raiz do Brasil (Cf. MACEDO, 1991,p.48).

A mesma imagem surge igualmente em "Pai Raiol, o feiticeiro".

Antes de seduzido pela lasciva e sensual Esméria, Paulo Borges é apresentado de forma modelar e lisonjeira. Visto positivamente como um empreendedor de caráter grave, Paulo Borges não se restringe a tomar conta da sua propriedade e dos seus escravos. Diligente e ambicioso, ele alarga os seus domínios, comprando mais terras e produzindo 
mais. Excetuando a crítica à compra de mais escravos em vez de máquinas, o fazendeiro configura mais um exemplo de como um senhor deve atuar, tendo em vista o desenvolvimento do país (Cf. MACEDO, 1991,p.80).

De maneira ainda mais significativa e paradigmática que a situação anterior para a constatação de uma mentalidade paternalista, surge o percurso e a postura de Teresa ao longo da trama. A mulher de Paulo Borges, «jovem, simples de costumes, honesta laboriosa» (MACEDO, 1991.p.79), reúne uma série de princípios elevados como a humanidade, a boa vontade, a ingenuidade, ao escolher para o seio familiar a escrava Esméria (Cf. MACEDO, 1991.p.84-5).

Inserida numa tradição macediana visível desde Mulheres célebres ${ }^{7}$, onde as mulheres são observadas como as «primeiras e principais reguladoras do futuro da pátria, como mães de família» (MACEDO, 1878,p.6), Teresa é delineada no texto não somente como o modelo do amor pela família, mas também como o exemplo da resignação perante a infidelidade do marido.

Assim, como em Mulheres célebres, onde se registam histórias exemplares sobre mulheres brasileiras, Macedo envida não apenas apelar às mulheres brasileiras do seu tempo para que ajam segundo as virtudes elogiadas em Teresa, mas, acima de tudo, realçar, pedagógica e preventivamente, que essa figura feminina representa os perigos a que uma senhora está sujeita, quando em contato próximo com os cativos:

— Morro envenenada por Esméria!... Eu te perdôo, se velares por teus filhos que ...

Não pôde acabar.

O envenenamento seguiu o seu curso, sua obra de destruição torturadora, sinistra, execrável ...

A pobre mártir subiu ao céu à luz da aurora. (MACEDO, 1991,p.121-2)

"Lucinda, a mucama", a terceira novela, percorre um caminho semelhante às anteriores na conceção de uma mundividência patriarcal, destacando-se fundamentalmente o comportamento de Leonídia e de Frederico.

Ao apresentar positivamente Florêncio da Silva como «afável e generoso», cedo se assiste à defesa do núcleo familiar, noção já mencionada (MACEDO, 1991,p.155). Tal ideia reforça-se ao longo da ação a partir da atuação da mãe e do irmão de leite de Cândida, que tentam a todo o transe protegê-la das ameaças escrava e estrangeira.

Logo no início do texto, num ambiente edénico de chácara, salienta-se o relacionamento fraterno entre Frederico e Liberato, o irmão de Cândida, o que reforça a 
harmonia do viver branco, como se tal vivência fosse exclusiva dele (Cf. MACEDO, 1991,p. $155)$.

Ora é nesse clima de idealização que emergem os perigos escravo e externo, fazendo com que as qualidades excecionais dos brancos nacionais se destaquem com maior acuidade.

Ao contrário de Souvanel, astuto e sedutor, que se fez «amar pela música», Frederico demonstra um caráter nobre e reto, ao perceber que Cândida amava o suposto foragido à justiça francesa (Cf. MACEDO, 1991,p. 214-6). Embora triste, pois amava Cândida, o jovem mancebo não desistiu de proteger a moça daquele que suspeitava desde o início ser embusteiro e da influência nefasta da mucama Lucinda (Cf. MACEDO, 1991,p.217-20). Esse procedimento de Frederico, norteado pelo instinto protetor que procura zelar pela segurança e bem-estar da sua família, representa simbolicamente a luta desesperada pela manutenção de uma mentalidade paternalista.

Assim, com Leonídia encarnando a família, Cândida, a vítima, e Frederico, o protetor, está representada alegoricamente a sociedade brasileira sujeita a uma dupla ameaça: a escrava, predominante na obra, e a estrangeira, que só consegue os seus intentos com o auxílio maléfico da mucama Lucinda e do «pajem fiel» de Florêncio da Silva.

\section{MACEDO E A MANUTENÇÃO DO STATUS QUO}

A partir dos exemplos expostos e dos apelos ao leitor-senhor-de-escravos, pode concluir-se que o fito de Macedo passa pela defesa da emancipação dos escravos, sob o risco de se degenerarem os costumes e a moral, se tal liberdade se não concretizar.

O elogio à generosidade senhorial, ao seu labor, os encómios ao papel protetor do homem, pai ou marido, e também do «seio vigilante» da mãe, a apreensão pela unidade familiar constitui exemplo dessa preocupação macediana (MACEDO, 1991,p.32).

Inserido num contexto social e político que acreditava na superioridade dos brancos sobre os negros, o escritor de Itaboraí, apesar de não ser fazendeiro proprietário de escravos, mas fazendo parte de um status quo instituído e cônscio do público-leitor a que se dirigia, sabia que não podia radicalizar o tratamento da questão abolicionista.

Seguindo a linha deste raciocínio, nessa «correspondência entre as expectativas dos leitores e as respostas que lhes deram os ficcionistas» que «explica sempre a polaridade 
realismo-idealismo que acompanha o romance da época» (BOSI, 1994,p.129), a noção que Macedo parece querer transmitir é a de que, naquele momento, era preciso encarar a emancipação dos escravos de forma moderada e progressivamente faseada.

Partindo da noção de que os escritores se configuram como construtores da história e formadores da identidade nacional, o que parece relevante questionar-se é se havia nessa conceção patriarcal evidente em Macedo um lugar para o homem de cor, ao apologizar-se a sua emancipação. Perante os dados apresentados, pode afirmar-se, sem grandes incertezas, que, para o autor de As vítimas algozes, não parecia ainda haver lugar para os negros nem para os crioulos ou mestiços.

$\mathrm{Na}$ verdade, estas novelas de Macedo não mostram a intenção de destruir o mundo a que pertence e que representa. Pelo contrário, o escritor não se distancia de uma atitude referencial, preferindo plasmar uma sociedade com a qual se identifica em grande parte.

Neste encadeamento, refira-se que a «arte do romance» macediana se limita lacunarmente a essa atitude de mostrar, porque, àquela altura, do desenvolvimento intelectual brasileiro, «era a sua a única arte possível de romance no Brasil». Por esta razão, deve-se ler Macedo «no contexto das expectativas de leitura do seu tempo e não pelo do nosso.» (MARTINS, 1996,p.300-1).

\section{O RACISMO E O ESTEREÓTIPO: AS CHAVES DO PODER}

Entre as décadas de 60 e 80 de oitocentos, atento aos desenvolvimentos e às controvérsias sobre o regime servil, o escritor brasileiro focaliza progressivamente mais exemplos de situações em que surge o escravo, com um duplo objetivo: primeiro, evidenciar a relação que existe entre senhores e escravos; segundo, estabelecer um processo comparativo, para demonstrar a superioridade de uma raça sobre outra. Através dessa intenção, percebe-se a excecionalidade e a humanidade do senhor sobre a vulgaridade e a bestialidade do escravo.

A definição de um imaginário social bem determinado, com os senhores numa situação de domínio e os escravos apenas obedecendo, permite asseverar que, no quadro de uma mentalidade esclavagista, As vítimas algozes esboçam um painel onde se notabiliza um esforço para manter as estruturas de uma sociedade bem estratificada. 
Pode mesmo dizer-se que estes textos em análise permitem estabelecer linhas ideológicas ou temáticas precisas que delineiam, conservadoramente, uma espécie de fórmula que potencia o «domínio branco» sobre o negro ou o mulato. Essas linhas, certamente influenciadas por diversos cientistas, pensadores e estadistas europeus e norteamericanos (Francis Bacon, David Hume, Immanuel Kant, Charles Darwin, Conde de Gobineau, Thomas Jefferson, Abraham Lincoln, Louis Agassis, e muitos outros), e até brasileiros como Tavares Bastos, passam pela apresentação de preconceitos rácicos e pela construção simbólica de imagens estereotipadas do escravo.

Desta forma, com uma conceção naturalista, onde se explicita uma tese, em As vítimas algozes percebe-se o desenho de uma mentalidade contaminada por preconceitos rácicos. Como enfatiza Dante Moreira Leite, o racismo «era a fórmula preciosa para justificar o domínio branco sobre o resto do mundo: se as outras raças eram biologicamente inferiores, se eram incapazes de atingir os valores mais elevados da civilização, só poderiam sobreviver como as massas trabalhadoras submetidas aos brancos.» (LEITE, 1992,p.131).

Assumindo essa ideia, delimitam-se no romance os contornos do que parece ser uma necessidade indispensável: conceber a imagem do escravo (Simeão, Pai Raiol, Esméria, Lucinda) ou do estrangeiro (Souvanel/Dermany) baseada na perversidade, na dissimulação, na ambição desmedida, na desonestidade, para que se distingam os traços de superioridade característicos dos senhores brancos brasileiros. Simeão - que encarna os crioulos bem tratados pelos senhores; Pai Raiol — o negro que é a imagem do ódio e da ameaça aos proprietários de escravos; Esméria e Lucinda - que traduzem a dissimulação e a perversidade; e, todos eles — o vício e a degradação moral que a escravidão provoca constituem personagens que parecem ter como finalidade determinar o perfil do brasileiro proprietário como generoso e honesto.

Em “Simeão, o crioulo", observa-se, entre outros aspetos, que à dissimulação e traição de Simeão se opõem o carinho e a generosidade de Angélica e Florinda; à desumanidade e desrespeito de Simeão se opõem a humanidade e excecionalidade de Hermano Sales.

O momento em que Hermano descobre as idas de Simeão a sua casa, para se envolver com a mucama do seu pai, reforça as suas qualidades extraordinárias e salienta, mais uma vez, a superioridade perante o escravo, castigando-o em frente de Eufémia. Parecendo defender o castigo físico ao escravo quando prevarica, essa passagem assume ainda maior significado, na medida em que se observa o reconhecimento pelo escravo da supremacia da 
raça branca que domina facilmente a negra: «Simeão viu desde então em Hermano um homem que era melhor, mais forte, e muito superior a ele: melhor, porque era livre; mais forte porque pudera e podia subjugá-lo; muito superior, porque o tinha esbofeteado, prendido e mandado preso à casa de seu senhor...» (MACEDO, 1991,p. 43-4).

A superioridade sobre o homem de cor aparece ainda demonstrada na apresentação do amor idealizado de Hermano Sales e Florinda contraposto ao de Simeão e da mucama de João Sales, Eufémia. A intenção é clara: mostrar que o amor animalesco dos escravos se opõe ao sentimento puro e platónico dos senhores: «havia dous anos, sabiam ser amados, correspondiam-se e em dous anos não se tinham falado uma só vez. Era um amor puríssimo», nitidamente oposto ao amor carnal, instintivo e lascivo dos escravos (MACEDO, 1991,p.47) . Segundo o narrador, os escravos «ajustaram-se», não se amaram.

Por seu turno, em "Pai Raiol, o feiticeiro" e "Lucinda, a mucama", surge bem vincada a ideia de que à dissimulação de Pai Paiol e Esméria se opõe a credulidade de Paulo Borges e Teresa; à indignidade de Esméria se opõe a honorabilidade e a capacidade de sofrimento de Teresa; à leviandade e perversão de Lucinda, se opõe a ingenuidade de Cândida.

Por outro lado, numa aproximação à mentalidade escravocrata, os defeitos, os vícios e até a própria aparência física caracterizada pela fealdade, são constantemente enfatizados como traços específicos dos escravos:

[Pai Raiol] homem de baixa estatura, tinha o corpo exageradamente maior que as pernas; a cabeça grande, os olhos vesgos, mas brilhantes e impossíveis de se resistir à fixidade do seu olhar pela impressão incômoda do estrabismo duplo [...]; quanto ao mais mostrava os caracteres físicos da sua raça; trazia porém nas faces cicatrizes vultuosas das sarjaduras recebidas na infância: um golpe de azorrague lhe partira pelo meio o lábio superior, e a fenda resultante deixara a descoberto dous dentes brancos, alvejantes, pontudos, dentes caninos que pareciam ostentar-se ameaçadores; sua boca era pois como mal fechada por três lábios; dous superiores e completamente separados, e um inferior perfeito, o rir aliás muito raro desse negro era hediondo por semelhante deformidade; a barba retorcida e pobre que ele tinha mal crescido no queixo, como erva mesquinha em solo árido, em vez de ornar afeiava-lhe o semblante; uma de suas orelhas perdera o terço da concha na parte superior cortada irregularmente em violência de castigo ou em furor de desordem; e finalmente braços longos prendendo-se a mãos descomunais que desciam à altura dos joelhos completavam-lhe o aspecto repugnante da figura mais antipática. (MACEDO, 1991,p. 82)

Reiterando a ideia de inferioridade do negro, não se estranham as associações frequentes à animalidade, à irracionalidade, à indigência, à ausência de sentimentos, e à incapacidade, por natureza, de aprender. 
Concebidos todos pela mesma medida como «ociosos, vadios e turbulentos» (MACEDO, 1991, p.10), não se estranha que, nas duas primeiras novelas de As vítimas algozes, se pressinta a desconsideração pela cultura negra, considerada também inferior quando em confronto com a ocidental.

Na festa de casamento de Florinda com Hermano Sales, em "Simeão, o crioulo", o narrador macediano, além de demonstrar que o contentamento dos cativos, insensíveis ao sofrimento de Domingos Caetano, se devia somente à «carne fresca assada, as sobras do banquete, o vinho e a aguardente», destaca que eles são detentores de uma cultura selvagem, animalesca e pouco civilizada: «A indiferença brutal dos escravos prolongava os fados, aturdindo a fazenda com a tempestade de suas músicas e de seus cantos selvagens.» (MACEDO, 1991, p.49).

A inferioridade da cultura africana surge também em destaque na segunda novela. No início de "Pai Raiol, o feiticeiro", depois de se fazerem considerações generalizadoras sobre a feitiçaria e outras práticas semelhantes de origem africana e os efeitos negativos que elas causam nos ingénuos e bondosos senhores, conclui-se que as manifestações culturais dos escravos, a música e o canto, são reflexo da sua selvajaria (Cf. MACEDO, 1991, p.72).

Por outro lado, o negro é visto pelo narrador como um agente desvirtuador e corruptor da língua portuguesa — a linguagem utilizada pelo negro é tida como «patuá do escravo» (MACEDO, 1991,p.11), «língua ou dialeto selvagem» e «algaravia bárbara» —, dos costumes e das santas crenças (MACEDO, 1991,p.95-6).

Na realidade, não reconhecendo a alteridade, Macedo rejeita a diferença dos hábitos culturais africanos, nem os concebe como tal. É por isso que, com o intuito de mostrar o efeito perverso da escravidão na sociedade brasileira, as manifestações culturais africanas são tão menosprezadas e tidas como grotescas e repugnantes, que sujeitam o senhor à indecência e sordidez de tais práticas:

Soam os grosseiros instrumentos que lembram as festas selvagens do índio do Brasil e do negro d'África; vêem-se talismãs rústicos, símbolos ridículos [...]; prepara-se o fogo, ou na velha imunda mesa, beberagem desconhecida, infusão de raízes enjoativas e quase sempre ou algumas vezes esquálida; o sacerdote rompe em dança frenética, terrível, convulsiva, e muitas vezes, como a sibila, se estorce no chão: a sacerdotisa anda como douda, entra e sai, e volta para tornar a sair [...], e no fim de uma hora de contorsões e de demônio, de ansiedade e de corrida louca da sócia do embusteiro, ela volta enfim do quintal, onde nada viu, e anuncia a chegada do gênio, do espírito, do deus do feitiço, para o qual há vinte nomes cada qual mais burlesco e mais brutal. [...].

Tudo isto é hediondo e horrível, mas é assim. (MACEDO, 1991,p.74-5) 
Desprezando tudo quanto é africano, Macedo, com um sentimento de intolerância, mostra também que a religião cristã é a única verdadeira. Para ele, as manifestações religiosas africanas são «absurdas», «falsas», corrompem os costumes e abrem «fontes de desmoralização.» (MACEDO, 1991, p.73).

Verifica-se, portanto, que a referência aos costumes dos escravos não é feita com o sentido de os resgatar, para construir uma história, como no romance Úrsula (1859), de Maria Firmina dos Reis, mas para destacar os seus aspetos mais selváticos, mais animalescos.

Já em "Lucinda, a mucama", é de registar a convicção do narrador na superioridade rácica do branco sobre o negro, no que diz respeito à sua capacidade racional, à sua inteligência (capítulo X). Tal como Hegel, o escritor acredita que, conquanto uma jovem branca tenha recebido pouca instrução é «pela sua posição e costumes tão superior em inteligência, tão elevada moral e socialmente», em relação à sua mucama, que se torna incompreensível que «se deixe influenciar e induzir por esta, a ponto de sacrificar o seu pudor para ouvir-lhe a lição perversa, que a sua própria consciência reprova.» (MACEDO, 1991, p. 180).

Para o autor de As vítimas algozes, o comportamento reprovável e a degradação moral Cândida devem-se unicamente ao contacto inoculador da escrava:

E na mucama escrava, na influência da companhia da escrava, da negra condenada à escravidão, desleixada, desnaturada, corrompida na escravidão, nessa peste animada, que invadira o seu aposento, ela encontrou, um por um, todos os princípios maléficos que a tinham levado à perdição. (MACEDO, 1991,p. 266-7).

Nesta perspetiva, mesmo que subtilmente, não passa despercebido o pensamento macediano sobre a formação do Brasil e dos povos que devem estar na sua essência e construção. Tendo conhecimento, por certo, das ideias racistas do Conde de Gobineau, não é casual a insistência nos casamentos de Hermano com Florinda ("Simeão, o Crioulo") e de Frederico com Cândida ("Lucinda, a mucama"). Numa leitura mais abrangente e de índole ideológica, é a noção de que a família brasileira só tem possibilidade de se formar com brasileiros brancos, excluindo negros e estrangeiros.

Em virtude das ideias expostas, verifica-se uma inversão dos efeitos da escravidão, salientando-se não o sofrimento dos escravos perante o sistema esclavagista, mas a insegurança e a vitimização dos senhores proprietários de escravos. Logo, o escravo torna-se algoz e o senhor, vítima: “Em circunstâncias tão inexprimíveis, pelo infinito horror da 
resultante afronta da família e escândalo da casa, a madre-fera escravidão exulta, pondo em torturas, envenenando, desonrando, desgraçando a vida dos senhores.” (MACEDO, 1991, p. 105).

A presença mais frequente do escravo na literatura desta época justifica-se, precisamente, por se ter tornado um constrangimento e um perigo para uma sociedade que se construía sobre princípios liberais. Para os brasileiros do século XIX, o negro era um ser sem qualquer poder, «estranho», que, para agravar a situação, punha em causa a segurança dos senhores com as fugas constantes e os assassinatos frequentes (Cf. SÜSSEKIND, 1982,p. 61).

Perante esta realidade, que imagem literária do escravo, do negro e do mulato, interessava traçar a uma sociedade que acreditava na hegemonia da raça branca sobre a negra? Que representação do escravo se encontra nestes textos de Macedo, conhecendo que ele estava inserido nessa sociedade preconceituosa e partilhava a mesma mentalidade? Estas são algumas das questões fundamentais que permitirão perceber que a representação elaborada dos escravos aponta para uma visão extremamente negativa do negro que, encarado como inferior, não podia pertencer a um povo, a uma nação brasileira.

Nesta linha de pensamento, compreender-se-á que outra das linhas temáticas que se desenha em As vítimas algozes, de maneira a legitimar o domínio branco e a escravidão, se prende com a construção simbólica de imagens do escravo que se convertem em estereótipos.

Ainda que assente em princípios como a liberdade e a igualdade, organização, a própria subsistência da sociedade brasileira, paradoxalmente, só era possível porque se mantinha um sistema esclavagista, que permitia a exploração do homem negro pelo senhor.

À semelhança de outros países escravocratas, a economia do Brasil fez-se dependente do trabalho escravo e tornou-se uma anomalia para a qual se exigia uma fundamentação que justificasse a ausência de liberdade do escravo. Foi nesta conjuntura que se concebeu a ideia de que os negros estavam abaixo da condição humana e que, por isso, não exigiam o direito e o respeito reconhecidos como prerrogativas humanas.

Seguindo esta lógica, Macedo compõe uma imagem estereotipada do escravo, que passa necessariamente por uma ideia fundamental, a sua desumanização.

Em traços gerais, numa perspetiva étnica ou apenas social, um estereótipo é, num duplo sentido, tanto causa quanto efeito de um julgamento prévio de um ser humano feito 
por outro, que tende a circunscrevê-lo socialmente, a observá-lo e, ao mesmo tempo, controlá-lo. Por outras palavras, com a criação de uma imagem padronizada do negro, objetiva-se a eternização da condição subserviente e a manutenção do domínio senhorial.

Num sentido complementar, o indivíduo que sofre um processo progressivo de padronização, segundo David Brookshaw, é alvo de um esvaziamento das suas características únicas e individualizantes. Para Brookshaw, os estereótipos congelam a personalidade, "apagam a individualidade, dotando o receptor com características que se adaptam ao ponto de vista a priori do percebedor em relação à classe social ou étnica, ou, ainda, à categoria sexual de sua vítima”. (BROOKSHAW, 1983, p. 10).

Deste modo, o cativo corporifica, numa dimensão interrelacional, aquilo que o senhor rejeita e nega. Para o branco, de uma forma geral, e para o senhor proprietário de escravos, de uma forma particular, que veem plasmado em si o modelo de racionalidade, de civilidade e da cristandade, não era admissível o que consideravam a ausência de religião, ou a aparente irracionalidade dos negros e dos mulatos, que se constatava nas suas alegadas inferioridade e infantilidade.

Mostrando o negro como tonto, destituído, e como um objeto manipulável, tornava-se igualmente mais fácil conceber uma imagem ilusoriamente ideal do senhor generoso e paternal (Cf. SÜSSEKIND, 1982, p.64-5).

Em As vítimas algozes, aquilo a que se assiste de modo predominante, convenientemente para uma população dominante, é a tentativa de mostrar o escravo como um ser mau, detestável, demoníaco. E, assim, estando subjacente um esforço de controlo social e étnico, estes indivíduos estereotipados reforçam, como afirma Brookshaw, «a incompatibilidade básica entre as culturas euro-brasileira e afro-brasileira, rivais pretendentes a uma identidade cultural nacional». De acordo com Brookshaw, essa «incompatibilidade remonta ao simbolismo original inerente às cores, a equação brancopureza e, portanto, moralidade versus preto-perversidade, logo, imoralidade.» (BROOKSHAW, 1983, p. 83).

Com um alcance social indesmentível, esse processo de transfiguração do real encetado pelos textos literários mostra a tendência generalizada de apresentar o africano num único sentido, etiquetado redutoramente, quase sempre, como selvagem, sem cultura e analfabeto, indigente, infantil, leviano, dissimulado, insensível, diabólico e imoral.

Neste sentido, o retrato do escravo em As vítimas algozes é o pior possível. 
Nas linhas que antecedem as novelas, onde a escravatura é descrita como «um mal enorme», que se deve exterminar, Macedo, preparando o público-leitor, afirma assertivamente que o escravo que vai ser apresentado não se assemelha a personagens negras de outros romances lidos na época caracterizados positivamente. Ele deseja que esses escravos sejam esquecidos, pois os que vai mostrar são terríveis. Segundo Macedo, o escravo, o homem que nasceu homem, num processo de endemonização, tornou-se fera.

Pelo motivo exposto, o cativo vai aparecer em As vítimas algozes como um ingrato, um inimigo, um dissimulado, um ser diabólico. Apresentados assim, os escravos constituem o exemplo paradigmático da tese que ele pretende explanar: a escravidão é um sistema que degrada toda a sociedade, escravos e senhores, transformando os escravos, que à partida eram as vítimas, em algozes, e o movimento inverso no que diz respeito aos senhores, tornando-se vítimas do terror negro e não algozes dos escravos.

Percorrendo traços das personagens que relevam certos padrões, demonstrar-se-á que no imaginário macediano, Simeão, Pai Raiol, Esméria, Lucinda e o pajem de Florêncio configuram o elenco duma espécie de quadro narrativo negro que se pretende exemplar.

Em "Simeão, o crioulo", os escravos que frequentam a venda, descrita com uma coloração naturalista que ajuda à degradação do negro, aparecem generalizadamente caracterizados como «vadios, turbulentos e viciosos», associados ao deboche, à embriaguez e à luxúria (MACEDO, 1991, p. 20).

Ligado ao mal desde cedo, o escravo surge no pensamento do narrador-autor não apenas como o repositório de todos os vícios, mas também como alguém irreversivelmente condenado a nunca modificar o seu comportamento: «O coração do escravo é escuro, tenebroso como noute de tempestade: é abismo profundo e sem luz coberto pela crosta da tristeza íntima e da desconfiança perpétua.» (MACEDO, 1991: 59).

Sendo alvo de um processo de desumanização progressivo, Simeão, que aparece como um escravo que odeia os seus senhores, é a imagem da ingratidão e da dissimulação. Exemplificativo é o momento em que, simulando preocupação com o estado de saúde de Domingos Caetano, vê o seu comportamento desmascarado pelo narrador. Vendo o desespero de Angélica e de Florinda, o crioulo limita-se insensível e instintivamente, a apreciar a beleza dos seios de Florinda que ficaram descobertos (Cf. MACEDO, 1991, p.29).

Após a morte de Domingos Caetano e a leitura do seu testamento, Simeão, que aguardava com «impaciência febril» as notícias da prometida e desejada liberdade, vê ruir o 
sonho, pois é mantido escravo de Angélica, enquanto ela viver. Então, associado a um tigre esfomeado, inquieto e obcecado pela liberdade e pelo dinheiro, passeia insanamente pelo bosque e pensa em vingar-se (MACEDO, 1991,p. 57).

O desenho desumano do escravo continua na segunda novela. Depois de se tornar emancipada e senhora da casa, Esméria, marcada pela presunção e soberba, decide de forma crudelíssima castigar as suas colegas escravas da cozinha, açoitando-as (Cf. MACEDO, 1991,p.144).

Malgrado estas referências à desumanização de Simeão e de Esméria sejam significativas, o processo de esvaziamento da humanidade é ainda mais percetível na figura de Pai Raiol.

Depois de os feiticeiros serem caracterizados como «embusteiros selvagens», assistese a uma persistente animalização do negro (MACEDO, 1991,p.71). Na ocasião em que se sabe o tipo de relacionamento entre Esméria e Raiol, o escravo é descrito como uma serpente, associada biblicamente ao veneno, ao pecado, à perfídia. A correspondência entre homem e animal é de tal forma que ele, ao deslizar por entre as folhas e as árvores do bosque e ao assobiar, imitando o silvo das serpentes, comunica com os répteis que respondem à chamada:

Uma vez, Raiol conduziu Esméria ao bosque e parando em um lugar onde mais se encerrava o cipoal assobiou por vezes, imitando os silvos das serpentes; em breve acudiram uma depois de outras três cobras ameaçadoras; o negro fixou os olhos sobre elas, segurou junto da cabeça em uma que se enrolou em seu braço, depois deixou-a livre e assim enrolada, ameigou-a, tirou-a do braço, guardou-a no seio e por fim soltou-a no chão. (MACEDO, 1991,p.88)

Tal ligação às serpentes alcança outra relevância por não ser pontual. Quase no final da novela, Raiol é de novo equiparado a uma cobra em duas situações: primeiro, quando se refere a influência poderosa de Pai Raiol sobre Esméria (Cf. MACEDO, 1991, p.125); depois, quando Lourença, a escrava velha açoitada por Esméria, conta a Paulo Borges que a sua amante, em conluio com Pai Raiol, maquinava a sua morte (Cf. MACEDO, 1991, p. 145).

Outro traço significativo atribuído ao escravo e visceralmente relacionado com a animalização diz respeito à insensibilidade. Se Simeão mostrara uma indiferença extraordinária ao sofrimento do generoso Domingos Caetano, a sua falta de sensibilidade adquire uma nova dimensão, quando se confrontam os laços amorosos dos negros com os 
dos brancos.

Não mencionando detalhes escusados, pois o assunto já foi aludido para salientar a superioridade da raça branca sobre a negra, é, contudo, indispensável salientar que os escravos, ao contrário dos senhores, não têm, na lente macediana, capacidade para sentir o amor senão numa perspetiva lasciva e carnal.

Na primeira novela, a comparação estabelecida entre a relação ajustada de Simeão e a mucama da família Sales e a ligação amorosa de Florinda e Hermano Sales permite concluir que, enquanto a primeira se baseia no contacto físico e no desejo animalesco, a segunda é idealizada e elevada a uma relação sacralizada (Cf. MACEDO, 1991, p.42-5).

Em "Pai Raiol, o feiticeiro" e em "Lucinda, a mucama", o escritor-narrador persiste na recoleção de pequenos episódios de relações entre escravos que corroboram a mesma tese: na segunda novela, depois de ter concetualizado o verdadeiro amor como «puro, honesto, suscetível, e como a água límpida» (MACEDO, 1991,p.107), o narrador, na relação entre o feiticeiro e Esméria, demonstra que, para os escravos, «a lascívia é que é amor» (MACEDO, 1991, p.143); na terceira novela, após referir que o amor entre os cativos é dominado por um sensualismo brutal, o narrador reitera que os escravos não têm capacidade para amar, pois «não compreendem o amor platônico», não concebem uma «intriga amorosa, nem cultos rendidos por cavalheiro à senhora sem reservado cálculo físico.» (MACEDO, 1991, p.190).

Com estas considerações, o que se veicula é que, no escravo, os sentimentos mais imediatos, mais instintivos são os que predominam, fazendo com que numa relação amorosa ele seja apenas movido pela sensualidade e mesmo pela devassidão.

A imagem negativa dos escravos construída por Macedo passa também por apresentálos como dissimulados, malignos e perversos.

Não esquecendo que Simeão poderia reunir em si a representação do negro dissimulado e traidor, por uma questão de economia e simultaneamente de abrangência, salientam-se Esméria e Lucinda.

A parte da ação em que Esméria tenta convencer a mulher de Paulo Borges a tê-la como sua mucama é ilustrativa de um comportamento nada inadvertivo. Nesse capítulo VI, aparentando humildade, simplicidade, e nenhuma petulância, Esméria mostra-se como a escrava mais obediente, submissa e trabalhadora, pois às perguntas da sua senhora respondia que sabia lavar, engomar e cozinhar. Então, agradada com as respostas, Teresa pediu ao marido que destinasse aquela escrava para os trabalhos da casa. Cautelosamente, o 
comportamento e o trabalho de Esméria, no início, não puderam ser melhores. Atuando como «escrava esperta, hábil e ativa» num «fingimento mais friamente calculado», a amante de Pai Raiol lavava, engomava e costurava melhor do que duas ou três escravas, ganhando o apreço da sua senhora (MACEDO, 1991, p.85).

Todavia, o fingimento da escrava não se limita às atividades domésticas. A atenção e o carinho dado aos filhos dos seus senhores pautam o seu comportamento e granjeiam-lhe o reconhecimento generoso de Teresa e de Paulo Borges. Essa atitude dissimuladora verificase sempre que Esméria arranja um presente para os senhores-moços - uma cigarra, um ninho ou outro objeto de distração (Cf. MACEDO, 1991,p.85) - , e quando, seguindo as instruções de Pai Raiol, simula afeição ao filho recém-nascido de Teresa e de Paulo Borges (Cf. MACEDO, 1991,p.103).

Com uma postura idêntica, surge Lucinda, na terceira novela. Depois de ter despertado propositadamente a curiosidade de sua jovem senhora para o namoro e a sedução, a mucama aparece em mais do que uma ocasião como o modelo da dissimulação. Quase no final da ação, omitindo a verdadeira intenção que era fazer com que Cândida caísse no estratagema do francês, a escrava aconselha-a, face às desconfianças da sua família, a ter cuidado na sua exposição com o amante, sem deixar, ainda assim, de salientar que Souvanel a ama loucamente (Cf. MACEDO, 1991,p.271). Noutra situação, depois do café com tártaro emético que causava enjoos e desmaios a Cândida, provocando a ilusão de que estaria grávida, Lucinda sugere-lhe o aborto, sabendo que ela recusará, e logo a seguir aproveita para insinuar o casamento dela com Souvanel/Dermany em segredo, para que os pais a perdoem depois (Cf. MACEDO, 1991, p.300-1).

Analisando estes exemplos, pode-se concluir que do fingimento estratégico e malicioso à traição vai um pequeno passo. O narrador-escritor pretenderá, assim, provar que os escravos desmoralizados arrastam os brancos para a perdição: Esméria, introduzindo-se no seio da família Borges, trai a sua senhora, seduzindo Paulo Borges, primeiro, e assassinando-a impiedosamente a ela e aos seus filhos depois; Lucinda, iniciando o processo de influência malévola sobre Cândida, indicia que ela ainda não é «moça» e provoca-lhe a curiosidade (MACEDO, 1991, p.169), ou mais tarde, quando incentiva a sua sinhá-moça a namorar e a conceder entrevistas a Souvanel.

Afinal de contas, aparentemente vítimas da opressão escravocrata, estas mulheres encarnam a traição dentro da casa do senhor e constituem-se o paradigma da perversão e do 
mal que os escravos inoculam aos senhores: «escrava perversa e devassa como todas as escravas mais ou menos o são.» (MACEDO, 1991, p. 222).

Com base no que se expôs, reconhece-se n' As vítimas algozes um processo progressivo e paradigmático de diabolização do escravo, para mostrar que, por ser uma ameaça ao senhor e não por se tratar de um ser humano, a libertação do escravo é imprescindível. Por isso, Macedo exemplifica nos seus quadros narrativos que, a persistir o sistema esclavagista, os senhores sofrerão toda a espécie de males vindos dos cativos: traição, desonra, morte.

Num momento inicial de "Simeão, o crioulo", aborrecido com o castigo físico que lhe aplicara Domingos Caetano pelo roubo que praticara, Simeão concebe pela primeira vez, de maneira sinistra, a ideia de ficar rico. O plano para roubar a família que o acolheu invadiu-o fatalmente e incendiou-lhe a ganância e a perversidade: «Simeão não riu; mas brilharam-lhe de súbito os olhos com flama sinistra. Luzira-lhe na alma uma idéia satânica.» (MACEDO, 1991: 25). Desse momento, à necessidade de matar a família que o acolheu foi um passo (capítulo XII).

De forma mais clara do que em Simeão, Pai Raiol surge desde os primeiros momentos como o símile do demónio.

Visto como «Demónio do mal e do rancor», o feiticeiro, evidenciando o seu caráter maléfico, deseja mal às crianças e a Teresa, que mostraram medo da sua figura: «O malvado escravo tomou em rancor as duas crianças, como tinha tomado em ranço Teresa...» (MACEDO, 1991, p. 93).

Contudo, a sua ação diabólica adquire uma amplitude maior, quando engendra o plano para matar os senhores - na sua visão, tigres —, e ocupar os seus lugares. Após ter aconselhado Esméria a que conseguisse um lugar dentro da casa-grande e se insinuasse a Paulo Borges, o negro terrível e manipulador insiste e ameaça-a, para que ela seduza o senhor e, assim, comece a causar-lhe problemas domésticos. O poder de matar estava nas mãos do feiticeiro e isso aterrorizava igualmente a mucama. Nessa sequência, o exemplo dos pintainhos que morrem só com o poder do olhar do feiticeiro impressionam-na e constituem o prenúncio do que iria acontecer a Teresa e aos seus filhos: «- Pai Raiol pode muito, e sabe matar com os olhos: Esméria quer ver?... [...]. De repente o primeiro pintainho caiu, depois sucessivamente todos os outros foram também caindo.» (MACEDO, 1991, p.100-1). 
A ação destruidora de Pai Raiol em conluio com Esméria atinge o auge, quando perpetram o envenenamento de Teresa, dos seus filhos e de Paulo Borges. Simbolicamente, a mensagem é terrível: a família brasileira corre o risco de morrer se não se exterminar a escravatura. Teresa e os filhos encarnam ficcionalmente o Brasil que definha sob a influência satânica dos escravos. Beneficiando do rancor de Lourença que se queria vingar de Esméria, só Paulo Borges se salva para, exemplarmentemente, punir os escravos assassinos.

\section{MACEDO: ABOLICIONISTA OU NÃO?}

Após se ter exposto o tipo de representação e imagem negativa de que o escravo é alvo, deve considerar-se a obra em análise como texto abolicionista? As vítimas algozes defende ou não a abolição da escravatura?

As situações que comprovam a defesa de uma abolição são várias.

Constata-se, todavia, que a desculpabilização e a vitimização dos senhores que se junta ao medo que sentem dos escravos, por um lado, a metaforização da escravatura, e sua amenização, que aparece como um acidente provocado pelo destino, e a apologia da submissão, por outro, se não colocam em causa o carácter abolicionista da obra, esmaecemlhe a intenção. Os escravos não constituem, verdadeiramente, a preocupação essencial do doutor Macedinho.

A defesa da abolição e a consequente emancipação dos cativos, pode-se afirmar, constituem-se, afinal, como uma estratégia dissimulatória para defender a manutenção de um status quo.

Como libelo anti-esclavagista, são visíveis, ao longo de As vítimas algozes, os frequentes apelos do narrador à supressão do que ele considera um «cancro», seja a partir de um discurso apaixonado, como no prólogo, em que considera indispensável à causa pública «iluminar os proprietários de escravos e convencê-los de que está em seus próprios interesses auxiliar o estado na obra imensa e escabrosa da emancipação», seja através de um discurso reiterativo, apelando ao fim da escravidão (Cf. MACEDO, 1991, p.4). 
No prólogo, numa espécie de texto programático e didático, Macedo dá a conhecer o que pensa sobre a existência da escravatura, que aparece caracterizada como algo que corrompe: «um mal enorme, que afeia, infecciona.» (MACEDO, 1991, p.1).

O escritor, por esse motivo, é explícito e apela aos fazendeiros, a quem se dirige particularmente, a fim de que defendam uma solução para o problema da emancipação dos escravos, que deve ser gradual. Com um tom profético, argumenta que, caso a emancipação progressiva não aconteça, acontecerão convulsões sociais ${ }^{8}$.

Macedo constrói, então, o cenário «veracíssimo» de que a escravidão «é peste» que degrada o ser humano (MACEDO, 1991, p.314). Desse ponto de vista, compreendem-se as insistentes referências às consequências nocivas que o sistema esclavagista provoca nos escravos-protagonistas das novelas. Se por um lado, Simeão deseja ardentemente a liberdade e Lucinda anseia por uma vida de prazer fora da sua condição, igual à da sua senhora, Pai Raiol, marcado pelos castigos infligidos pelos senhores, tenciona tomar o lugar de Paulo Borges como proprietário da fazenda.

Tais intenções servem igualmente de argumento para os apelos melodramáticos em prol da abolição, sobretudo no final de cada uma das novelas.

Exemplificando, em "Simeão, o crioulo", depois de se denunciarem os crimes do protagonista e de se afirmar que «a escravidão degrada, deprava, e torna o homem capaz dos mais medonhos crimes», o fim do sistema escravocrata é apontado como a única solução para acabar como os inúmeros Simeões que, generalizadamente, contaminam a sociedade brasileira: «Se quereis matar Simeão, acabar com Simeão, matai a mãe do crime, acabai com a escravidão.» (MACEDO, 1991, p. 68).

Já em "Pai Raiol, o feiticeiro", seguindo a mesma estratégia narrativa da novela anterior - apontar primeiro os crimes praticados pelo maquiavélico feiticeiro e pela sedutora e dissimulada Esméria —, insiste-se em referir que, apesar de terem sido castigados com a morte, a escravidão persiste, deixando entender que as mesmas situações se podem repetir: «A escravidão, porém, continua a existir no Brasil. E a escravidão, a mãe das vítimas-algozes, é prolífica.» (MACEDO, 1991, p.152).

Em "Lucinda, a mucama", é Frederico quem, votando Lucinda e o pajem devassos ao abandono, apela, repetida e teatralizadamente, ao fim da escravidão (Cf. MACEDO, 1991: 314). 
No entanto, contrariamente à intenção autoral proposta inicialmente ${ }^{9}$ e àqueles que veem no texto de Macedo um intuito vincadamente abolicionista ${ }^{10}$, As vítimas algozes, mais do que questionar a legitimidade da escravatura imposta e mantida pelos senhores e mais do que denunciar os sofrimentos infligidos aos escravos, parece erigir-se como um documento de argumentação que pretende expor as consequências negativas que a escravatura provoca numa classe que se começava a dividir. Por isso, de modo análogo, os três textos apresentam escravos inimigos que vão provocar a morte, o sofrimento, a degradação moral.

Principiando por afirmar que o mal de tudo veio de África, Macedo, de forma generalista e numa lógica de causa-efeito, considera que o negro reduzido à sua condição escrava provocou a degradação da sociedade, inoculando-lhe uma série de vícios. E dessa forma dá-se a conhecer o processo de inversão no sistema escravocrata: a vítima afinal é o algoz, enquanto o opressor é vitimizado.

Como Simeão, Pai Raiol e Esméria, ambos, maléficos, vão causar a decadência de Paulo Borges e a morte da restante família, que, alegoricamente, como a de Domingos Caetano ou de Florêncio da Silva, representa a família brasileira que se sente ameaçada pelos escravos.

Pai Raiol, com os seus dotes da perversa feitiçaria, provoca incêndios, causa a morte de animais, industria Esméria no sentido de ela seduzir Paulo Borges, e, posteriormente, convence-a facilmente a envenenar sucessivamente Teresa, os filhos e o amante.

Com lugar de destaque na segunda novela, o sofrimento e a morte causadas a Teresa e aos filhos trazem à tona todas as emoções e provocam o medo, mas é sobretudo a progressiva degradação moral de Paulo Borges que abandona a mulher honrada e fidelíssima, que constitui a prova de que os senhores sofrem um processo degenerativo, quando em contacto com os escravos. Com um tom moralizador, considera-se que a «torpeza da escravidão é contagiosa e se inocula na vida doméstica do senhor que ousa expor-se ao contacto vergonhoso com a escrava.» (MACEDO, 1991, p.104). Paulo Borges, o paradigma do fazendeiro trabalhador e simples, deixa-se dominar pelas emoções e acaba enredado na teia de uma «paixão criminosa e torpe», desprezando o «amor honesto e puro» de Teresa e descuidando a atenção que devia prestar aos seus filhos, o que lhes causou a morte (MACEDO, 1991, p.115).

A função de Lucinda no último texto deve ser encarada, precisamente, nos mesmos moldes das personagens referidas anteriormente, influenciando negativamente a sua senhora. 
O processo de degradação que Cândida sofre é, talvez, o mais completo de todas as novelas, uma vez que antes do aparecimento de Lucinda é mostrada como angélica e pura.

A metamorfose de Cândida, passando da pureza ao pecado, é, pois, suscitada pelas ações de Lucinda que, qual «charco» sobre a «fonte límpida», lhe fala em namoros, lhe leva bilhetes dos namorados encontrados nos bailes, ou lhe excita as emoções, falando de intrigas amorosas. Fruto desta influência permanente e com a ajuda prestimosa da curiosidade e da vaidade da jovem senhora, o que se assiste é a uma progressiva dependência de Cândida a Lucinda. A mucama, dominadora da sua sinhá-moça, é vista como escrava-mestra, que dá uma lição «agreste, escabrosa e imoral», como se pode constatar no momento em que a ensina a omitir informações à mãe. Aprendendo com a mucama a dissimulação e a mentira, Cândida tornou-se «escrava de sua escrava», e reitera mais uma vez a tese de que o escravo, primeiramente vítima, se torna algoz e castiga o senhor (MACEDO, 1991, p. 173).

Se os dados apresentados permitem perceber a intenção de apresentar a escravatura como culpada da degradação sociedade brasileira, que leva Macedo a defender a emancipação gradual dos escravos, não deve, porém, esquecer-se que o que motiva essa intenção não é a humanidade dos escravos que ele tenta a todo o transe negar, mas o perigo que eles constituem para uma sociedade senhorial.

Daí, poder dizer-se, ou pelo menos questionar-se, se os textos que compõem $A s$ vítimas algozes não constituirão uma tese, uma teoria de dissimulação. Na verdade, mais do que abolicionistas, as novelas, que mostram os escravos criminosos, são pretexto para defender a sobrevivência dos senhores, face à ameaça escrava.

Desta maneira, entende-se a existência, ao longo do texto, de uma clara desculpabilização dos senhores, o que leva a concluir que Macedo, concebendo um narrador-senhorial, apenas pretende cortar com as amarras do sistema esclavagista, em virtude da degradação moral (Paulo Borges, em "Pai-Raiol, o feiticeiro", e Cândida, em "Lucinda, a mucama") e económica (Paulo Borges, em "Pai-Raiol, o feiticeiro") dos fazendeiros e proprietários de escravos. E é por isso que se pode afirmar que ao mesmo tempo que ocorre a endemonização do escravo se assiste à vitimização do senhor.

Logo nos primeiros parágrafos do prólogo, quando se tenta convencer os proprietários a enveredar por uma emancipação gradual dos escravos, Macedo não resiste à tentação de absolver o senhor: a escravatura é descrita como um «quadro do mal que o senhor, ainda sem querer, faz ao escravo» (MACEDO, 1991, p. 4). 
No entanto, é nas duas últimas novelas em que esse quadro se torna mais evidente. Em "Pai Raiol, o feiticeiro", ainda na parte em que se formulam considerações gerais sobre a feitiçaria dos escravos, diz-se que os senhores que assistem a tais práticas o fazem porque são crédulos, simples, supersticiosos (Cf. MACEDO, 1991, p.75).

Quase a seguir, apesar de ambiguamente considerar a escravatura humilhante e criticar o senhor por perpetrá-la, o narrador considera correto e justo que se puna exemplarmente o escravo: «o senhor nunca punia sem razão» (MACEDO, 1991, p. 80).

Igualmente na segunda novela e antes do «choro compungido» (MACEDO, 1991, p. 123) do fazendeiro, pela morte de Teresa, relevam-se atitudes como o remorso, o choro, o empalidecimento que tendem a apresentá-lo como um ser que tem a capacidade de se emocionar e de se arrepender por ter trocado a esposa pela escrava.

Em "Lucinda, a mucama", a estratégia projetada pelo narrador para destacar a vitimização da amada de Frederico é similar. Embora vaidosa, curiosa, e incentivadora dos namoros, Cândida, cujo nome é já simbólico dessa ausência de culpas, é, a partir de meio da intriga, sistematicamente alvo de um plano preciso do escritor: mostrar que a jovem senhora só agiu assim em virtude da influência maléfica de Lucinda. Subtraindo-lhe todos os vícios, Macedo mostra que não se pode conceber uma descendente de dignas famílias como culpada da sua própria degradação moral. Os únicos culpados, para Macedo, só podem ser os escravos, ou então, em algumas circunstâncias, como já se referiu, os estrangeiros (Souvanel) e os brancos pobres e andrajosos (o Barbudo).

Pelo que se apresentou, a arquitetura de um plano desculpabilizador das atitudes e comportamentos senhoriais serve um desiderato concreto e necessário: demonstrar que com a prossecução dum sistema esclavagista se assistirá a uma inversão social, em que o senhor será a vítima dependente do escravo que, em virtude dos crimes, se tornará senhor. Foi o que aconteceu com Esméria, tornando-se senhora da casa de Paulo Borges. Foi o que quase aconteceu com Pai Raiol, caso Paulo Borges tivesse morrido com o envenenamento do café. Foi o que aconteceu com Cândida que progressivamente se tornou escrava da sua escrava: «A escrava vendia ou revendia a senhora» (MACEDO, 1991, p. 273). Ora este aspeto constitui a inversão completa que se prepara ao longo do texto: os senhores são tão vítimas que já não vendem escravos, antes são vendidos por eles. Esta é a tese de Macedo. 


\section{OS EFEITOS DA «MADRE-FERA»}

O texto As vítimas algozes, dramática e dissimuladamente, metamorfoseia-se, assim, em máscara do medo senhorial: «O escravo é necessariamente mau e inimigo de seu senhor. A madre-fera escravidão faz perversos, e vos cerca de inimigos» (MACEDO, 1991, p. 29).

Um exemplo paradigmático do que se afirma acontece, quando Florêncio da Silva, Liberato e o seu pai, juntamente com Frederico, discutem a problemática da abolição da escravatura. Apaixonadamente, Liberato, para defender a emancipação dos escravos, fundamenta-se na afirmação de que os escravos constituem «inimigos de portas adentro» (MACEDO, 1991,p. 264). Por seu turno, Florêncio, ingénuo, diz que não compreende esse comportamento se os trata bem, paternalmente. Liberato tenta acordar o pai para a realidade nessa conversa sobre os escravos e a sua influência, dizendo que nem Florêncio é pai, nem eles, os cativos, filhos, que eles não são educados, odeiam, e são imorais nos costumes.

Acabando por concordar com o filho, de que eles guardam «em casa a peste», Florêncio assume a atitude que Macedo pretende para os proprietários: ao compreender o perigo escravo, que aceitem a abolição (MACEDO, 1991, p. 264).

Com este raciocínio, tal como Flora Süssekind, que parte da mundividência de Debret e nomeadamente de duas cenas de sua "Malhação de Judas do Sábado de Aleluia" (1839) que configuram uma inversão da ordem escravocrata, onde os senhores são os judas castigados e os escravos os castigadores, pretende mostrar-se que Macedo procura «amedrontar a população branca e sugerir como única solução possível para tais 'malhações' inesperadas uma emancipação gradual dos escravos com plena indenização para seus senhores por parte do governo.» (SÜSSEKIND, 1993,p.115).

Tal solução que enforma a tese central do autor da Luneta Mágica, incessantemente reiterada desde o prólogo às conclusões de cada um dos quadros-exemplo de escravidão, adquire uma nova dimensão com a necessidade de construir «um perfil aterrorizante para o escravo, misto de tigre e serpente, de vítima e algoz, capaz de atacar quando menos se espera.» (SÜSSEKIND, 1993,p.117).

Desta forma, é a máscara do terror diante do «perigo negro» quem ocupa a centralidade narrativa em As vítimas algozes, espelhando, na expressão feliz de Flora Süssekind, um «imaginário do medo» (SÜSSEKIND, 1993,p.124). 
A partir destes dados, explicam-se as obsidiantes referências às traições e à capacidade de dissimulação da população escrava, nomeadamente, dos que trabalhavam dentro de casa, crioulos criados com toda a afeição, mucamas, pajens. Todos eles constituem os exemplos dos escravos-ameaça, diabolicamente perversos, que aviltam e matam os senhores. O apelo do narrador para que o público-alvo tome cuidado com o perigo escravo, no final do capítulo III de "Pai Raiol, o feiticeiro", é bem a prova do que se afirma: «E tomai sentido e precauções: o escravo, não nos esqueceremos de o repetir, é antes de tudo natural inimigo de seu senhor; e o escravo que é feiticeiro sabe matar.» (MACEDO, 1991,p.78).

Expressiva no levantamento de situações que comprovam esse clima é a associação de Pai Raiol a um monstro negro que assustava as crianças. É Luís, o filho mais velho de Paulo Borges quem, ao ver o escravo feiticeiro pela primeira vez, premonitoriamente o identifica como o ser terrível que há de perder a sua família. É Luís quem serve de paradigma ao narrador para mostrar que, desde a mais tenra idade, o senhor sente, não apenas medo da figura, mas também receio de perder a sua vida e a sua família (Cf. MACEDO, 1991,p.923). A forma como o branco vê o escravo, moldada logo na infância, é muito simples e, simultaneamente, redutora - o negro, o escravo, estavam associados ao mal: «Em muitas histórias e baladas, por exemplo, o negro simboliza o demônio. A fusão negro-demónio logicamente produziu a imagem do Negro qua Negro, possuidor pelo menos de características semelhantes às do demónio, enquanto que o Demónio mesmo disfarçava-se de Negro» (BROOKSHAW, 1983: 13).

Portanto, não é a preocupação com a situação miserável dos escravos, as humilhações que sofrem, as punições que lhes são infligidas, a ausência de uma educação que os possa preparar para uma vida após a emancipação, que preocupa Macedo, mas, numa visão paternalista, a defesa dos esclavagistas.

\section{JOAQUIM MANUEL DE MACEDO AND THE SLAVERY ABOLITION}

ABSTRACT: After the abolition of the slave traffic, but before the laws of the "Ventre Livre" and the "Sexagenários", and the law "Áurea", Joaquim Manuel de Macedo trace in As vítimas algozes a plan against slavery aimed at its abolition. In this perspective, as a abolitionist text, are notorious the narrator's constant appeals to the abolition of what he 
considers a «cancer» that corrupts and degrades the human being. Stating that the evil of all came from Africa, Macedo considers that the reduced to his slave condition caused the degradation of society, seeding him a series of vices. In this way, it is to know the process of reversal in the slave system: the victim, after all, is the murderer, while the oppressor is victimized.

KEYWORDS: Literature; Slavery; Abolitionism.

\section{NOTAS}

1 Numa conceção muito próxima à de Robert Blauner (1970), quando explica a desculturação forçada infligida aos escravos afro-americanos pelos senhores das grandes plantations nos Estados Unidos da América, no Brasil, ocidentalizando-se os cativos, ora através de um processo secular e jesuítico de cristianização, ora através da obrigatoriedade de tarefas laborais impiedosas, assistiu-se a uma assimilação de raiz europeizante e, ao mesmo tempo, de um recalcamento dos costumes culturais e dos valores que permitiam a identificação e a individualidade desses povos despojados.

${ }^{2}$ Outras narrativas, embora retratem o negro, não problematizam a escravidão nem tão pouco a abolição. É o que acontece com Maria ou a menina roubada (1852-3), de Teixeira e Sousa; Cenas do interior (1865), de Luís José Pereira Silva; O coronel sangrado (1877), de Inglês de Sousa; Mota Coqueiro ou a pena de morte (1877), de José do Patrocínio; e $O$ cromo (1888), de Horácio de Carvalho; O bom crioulo (1895), de Adolfo Caminha; A mulata (1896), de Carlos Malheiro Dias

${ }^{3}$ Entendendo o texto literário numa dimensão ampla e relacional com outros sistemas e com uma dimensão ao mesmo tempo sintagmática e paradigmática, deve considerar-se que existe e permanece entre quaisquer textos uma margem comum, um ponto de encontro temático que, mais do que uma fronteira precisa, é o «transbordamento de um limite». Assim, entre dois textos coexistem, necessariamente, aspetos temáticos com uma abordagem idêntica num mesmo momento ou não por diferentes escritores, um «tecido de diferenças de força que une textos de um mesmo autor, textos de autores diferentes entre os quais exista alguma ligação; que une inclusive os valores da sociedade à qual o[s] autor[es] pertença $[\mathrm{m}]$, e que se manifestam também através de práticas discursivas.» (GOMES, 1981: 24-5). 
${ }^{4} \mathrm{O}$ «primeiro drama social real a incluir um personagem negro é $O$ demónio familiar, de José de Alencar [...]. Sua oposição à escravidão, tal como se demonstra no seu drama, não se baseava nos males que afligem os negros, mas se fundamentava na influência perniciosa da instituição sobre as famílias dos donos de escravos.» (RABASSA, 1965: 90).

5 Inocêncio Francisco da Silva afirmava que Macedo era um ser extraordinário, «abolicionista, antes mesmo de se ter manifestado este movimento emancipador.» (SILVA, 1884: 110-1).

6 Aspeto não despiciendo na configuração da mentalidade paternalista brasileira diz respeito ao facto de a noção de família ser entendida como exclusiva dos brancos, como afirma Louis Couty, em A escravidão no Brasil (1881). Para ele, os escravos são dominados pela lascívia: «Em meio a diversas centenas de milhares de escravas, não encontraremos nenhuma que não considere uma honra ou um prazer o fato de merecer a preferência de seu senhor.»(COUTY, 1988: 95).

${ }^{7}$ Neste texto há uma total ausência de referências a mulheres negras. Nele, o que se configura é uma espécie de cartilha que explicita como deve ser a educação no Brasil, reforçando o apelo a uma educação baseada no conselho prático e na explicação, na moralidade: «tornar bem o mal, mudar o vício em virtude.» (MACEDO, 1878: 11).

${ }^{8}$ Apelando neste sentido, é curioso verificar que Macedo, decerto sabedor das leis que se preparavam a favor de uma emancipação gradual, antecipa a publicação da Lei Rio Branco, em 1871, dando lastro a que se afirme que as novelas de As vítimas algozes foram encomendadas pelo imperador Pedro II, a fim de preparar psicologicamente os proprietários de escravos.

${ }^{9}$ Macedo pretendia tornar evidente as «misérias tristíssimas, e os incalculáveis sofrimentos do escravo, por essa vida de amarguras sem termo, de árido deserto sem um oásis, de inferno perpétuo no mundo negro da escravidão» (MACEDO, 1991: 4).

${ }^{10}$ Veja-se como, já depois da morte de Joaquim Manuel de Macedo, Inocêncio Francisco da Silva vê As vítimas algozes: «Espírito esclarecido e humanitário, compreendeu facilmente que a escravidão era uma moda que enlameava a nossa civilização, e para apagá-la empregou o concurso de sua pena, escrevendo As vítimas algozes, aquele arranco heróico do pulso contra as cadeias. Era abolicionista, antes mesmo de se ter manifestado este movimento emancipador que atualmente de se nota.» (SILVA, 1884:110-1). 


\section{REFERÊNCIAS}

BLAUNER, Robert. "Black culture: myth or reality", in WHITTEN, Norman, and SZWED J. (orgs), Afro-American Anthropology, New York, 1970.

BOSI, Alfredo. História concisa da literatura brasileira, São Paulo, Cultrix, 1994.

BROOKSHAW, David. Raça e cor na literatura brasileira, 3. ${ }^{\mathrm{a}}$ ed., Porto Alegre, Mercado Aberto, 1983.

COUTY, Louis. A escravidão no Brasil, Rio de Janeiro, Fundação Casa de Ruy Barbosa, 1988.

FREYRE, Gilberto. Casa grande e senzala, Lisboa, Livros do Brasil, 2002.

GOMES, Heloisa Toller. O poder rural na ficção, São Paulo, Ática, 1981.

GORENDER, Jacob. O escravismo colonial, São Paulo, Ática, 1980.

LEITE, Dante Moreira. O carácter nacional brasileiro, 5. a ed., Rio de Janeiro, Ática, 1992, p. 131.

MACEDO, Joaquim Manuel de. Mulheres célebres, Rio de Janeiro, B. L. Garnier, 1878. As vítimas algozes: quadros da escravidão, 3. ${ }^{a}$ ed., São Paulo, Scipione, 1991.

MARTINS, Wilson. História da inteligência brasileira, v. 3, 3. a ed., São Paulo, T. A. Queirós Editora, 1996.

RABASSA, Gregory. O negro na ficção brasileira, Rio de Janeiro, Edições Tempo Brasileiro, 1965.

SILVA, Inocêncio Francisco da. Dicionário bibliográfico Português, Lisboa, Imprensa Nacional, 1884.

SÜSSSEKIND, Flora. O negro como arlequim: teatro e discriminação, Rio de Janeiro, Edições Achiamé, 1982.

Papéis Colados, Rio de Janeiro, Editora UFRJ, 1993. 